\title{
UTILIZATION OF E-SABAK IN THE STUDY OF NATURAL SCIENCES IN THE FOURTH GRADE OF ELEMENTARY SCHOOL
}

\author{
(Descriptive Study on Science Learning In Grade $4^{\text {th }}$ of State \\ Primary School of Pondok Petir 01, Bojongsari, Depok City)
}

\author{
Muhammad Fajri \\ State Primary School of Pondok Petir 01, Reni Jaya Selatan St., Pondok Petir, \\ Bojongsari, Depok City, West Java \\ guru.penulis.fajri27@gmail.com
}

ABSTRACT: The purpose of this study was to describe the use of e-sabak in natural science learning in grade $4^{\text {th }}$ of Pondok Petir 01 State Primary School, Bojongsari, Depok City. The study used a qualitative approach with descriptive methods for photographing science learning processes using e-sabak devices both inside and outside the classroom. Learning is done in elementary schools to optimize students' ability to analyze and criticize their environment. The problem of learning science in grade $4^{\text {th }}$ elementary school is the practice of verbalism through learning. The use of e-sabak devices is able to answer the challenges of $21^{\text {st }}$ century learning. The step of learning to develop through the principle of "alam takambang jadi guru" by utilizing the environment as learning. The results of observations with the help of e-sabak devices were discussed and resolved in accordance with the study of the material studied by students. Research results for students are more serious in the learning steps. Students are more challenged and interested in returning to the environment class that discusses the material being studied. Students' communication skills and fattening through the stages of demonstration and presentation in front of the class based on their observations. From this device, science can be used in grade $4^{\text {th }}$ of Pondok Petir 01 State Primary School, Bojongsari, Depok City.

Keywords: e-Sabak, science learning, students in 4th grade of primary school

\section{INTRODUCTION}

Globalization has influenced many aspects of human life both individually and as social members in society. The process influences one of them in the educational process that manifests the side of life to prepare future generations who are ready to answer the challenges of the times. Students as future generations need to be equipped with a variety of competencies that can be relied on so that they are able to 
compete in the global domain as citizens of the international community later. In the future, we need human beings who have a progressive mindset and are able to predict every opportunity and phenomenon that has never existed from things that are impossible to be possible and from things that might become certainty. However, it takes great effort to cook up future generations who are truly capable in all fields fighting against the onslaught of globalization that is very fast and unpredictable.

What happens in the global realm is a phenomenon that develops along with the rapid development in various sectors of life. In this context, it is not what happens that needs to be thought about but more about how it is applied. What develops in a series of life processes needs to be faced with the readiness of superior and combat ready resources. Therefore, it is necessary to provide a variety of optimal competencies in order to be able to develop and optimize phenomena that develop as potential resources in improving and improving the standard of human life itself. In addition to civilizations that must be built and developed, it is also necessary to think about how humans themselves are able to live and develop with conditions that exist in the past. For example, nowadays the rice we eat at any time is very easy to find in our country. However, it could be several decades into the future because the agricultural sector is considered less profitable so that globally the life process changes to the industrial sector. In the end, agricultural lands disappeared slowly but surely resulting in a food crisis which meant that food commodities other than rice were necessary.

The effort to improve the quality of life by improving civilization in a better human life needs to be supported by serious efforts through the best education process. A business that will never be in vain but requires a lot of real thoughts and actions in the series of educational processes in the special education unit. The urgent thing that exists now is how our students are now able to definitely develop and think forward in a progressive context so that they can easily adapt to any environment. Being able to easily develop the resources they have is a definite opportunity to progress and develop. With all the phenomena and challenges facing them, they don't budge and remain focused on improving the quality of life they live in the future. Improving the quality of life through a series of planning, development, implementation, and evaluation of the educational process also requires serious and continuous efforts. Improvements in the context of quality refer to the creation of 
future generations as superior resource capital for the creation of the next 2045's gold generation. Optimizing superior programs through operational praxis in elementary schools, for example, can be done through a simple but sure andcontinuous effort. The consistent consistency is intended so that students are accustomed to thinking and working in challenging conditions and not just sitting relaxed and silent. Their silence is silent to think and solve problems in the context of learning in their class. They are actively active in a series of learning processes discussing and solving problems according to the context of the material being studied.

Effective learning must be able to develop students' abilities optimally as competencies are to be achieved. The learning process will run effectively if what has been prepared and planned can be carried out optimally in the series of learning processes themselves. The learning will be meaningful if students are consciously able to identify the new competencies they have acquired after carrying out a series of learning processes with their classmates. In addition, meaningful learning will be able to equip students in the context of skills and abilities that are useful in the series of life processes that they live in real life.

In the context of classroom learning, students will totally optimize the opportunities to learn and develop. In elementary school in particular, the learning process is carried out by referring to the aspects and tasks of the student's own development. In this case, students are the only basis and reference to what and how the learning is carried out. In addition, students are also the only basis for consideration regarding how learning is planned, developed, and implemented in a practical manner in the classroom. The material developed is also the result of consideration regarding the condition of students in the realm of developmental psychology and learning. Readiness is also the basis for consideration of how the series of learning processes from the simple to the complex is carried out.

The content of natural science learning is developed in the learning process to optimize students to be able to read and develop various issues and phenomena within the scope of natural phenomena. To optimize the learning that is done, various progressive steps are needed so that students are optimally able to master the expected competencies. Therefore, various effective and relevant learning methods and media are needed so that the learning process can be carried out optimally. The effort can be made by using a device in the form of learning aids that 
are able to optimize the learning process itself. In this context, one of the media that can be used is in the form of technology-assisted learning devices in the form of esabak. E-sabak itself is a name used by brand holders of PT. Telkom Indonesia as an effort to participate in building civilization in the scope of education, especially in educational units, is practically operational through the provision of teaching materials and learning tools that can be optimized for various learning processes both inside and outside the classroom.

In the context of technological developments and globalization, e-sabak devices have been designed to be able to provide various information needed today. In fact, even in the future conditions can be predicted in a limited way through this e-sabak device. In addition, e-sabak answers the challenges of the development of the era in relation to the use of modern and innovative technology products in the series of learning processes carried out. Another advantage also lies in the physical strength of the e-sabak device in the form of a Tablet PC for students. The physical advantage is that the user subject is a student who in some cases is still not too quick to hold the PC Tablet in his hand. Therein lies the physical superiority of the Tablet PC used because it is quite strong and sturdy when the device falls in a height of less than 1 meter above the hard and sturdy ceramic floor.

The use of e-sabak has been widely used in several schools, especially those in the Depok City area, West Java. However, the use of these devices is still very limited because based on existing releases, only 12 elementary and junior high schools were given the opportunity to use the e-sabak package from PT. Telkom Indonesia. As for the following year (2017) there were 18 schools that were given the same opportunity. One of the schools that got the opportunity was State Elementary School of Pondok Petir 01, Bojongsari, Depok City, West Java. Therefore, this report was made to photograph how the use of e-sabak in an effort to optimize the learning process, especially natural science at the school. The purpose of this study was to describe how the use of e-sabak in optimizing the learning process of science learning content in the fourth grade of state elementary school of Pondok Petir 01, Bojongsari, Depok City, West Java.

\section{LITERATURE REVIEW}


Challenging learning is ideally able to make students think and work hard and be smart in following the learning process sequence. Careful planning by the teacher in developing step by step learning requires carefulness and precision with consideration in aspects of student development and learning assignments. The relevance of the expected competencies with the aspects of development and student learning tasks becomes a necessity that cannot be replaced. This neverending process will become a series of continuous learning cycles in which the teacher always strives to improve and improve the series of learning processes carried out. Nothing else is for the creation of ideal learning and in accordance with what is aspired.

There is an assumption that says that the whole set of learning is a process of development or practice with thought (Hamalik, 2011, p. 36). These assumptions provide a view if self-study is a series of operational processes that involve a person's brain against a phenomenon that he observes. In this context, learning occurs because of the object of the problem or the learning content that is the study that is learned. Thus, the learning process will occur if students have the opportunity to think and act according to the context of the material learned in the scope of the learning process itself. Continuous exercise and training will have long-term effects on students' memory so that what they learn can be stored well in their long-term memory.

In the American Heritage Dictionary it is said that learning has 3 objectives, including: (1) gaining knowledge; (2) comprehensive; (3) mastery through experience or learning (B.R. Hergenhahn, 2008, p. 2).

The learning objectives themselves are the intended goals as the learning process is carried out. The implication is that the preparation of learning in the context of the intended learning plan must be able to develop and optimize the implementation of learning in the steps of the learning practice developed. Thus, a meaningful learning process will be achieved in accordance with the ideals and expectations aspired.

The learning process in elementary school is basically developed through the context of integrated thematic learning. Integrated learning is said by Colins in 
Trianto that through an integrated learning process students get two benefits, namely learning from the learning experience they experience (the learning process) and connecting the materials that are related to one another (Trianto, 2007, p. 7). Thus, integrated learning can facilitate the teacher itself through the development and interconnection between the material, at least it can facilitate the teacher in managing and developing learning material and can prepare the learning design better. In addition to facilitating the teacher, students also gain experience as well as comprehensive knowledge because the learning process sequence is not partial. In this context all the interrelated themes are connected and integrated in a series of learning processes so that students get their understanding and learning experience. Thus, integrated learning can facilitate the teacher itself through the development and interconnection between the material, at least it can facilitate the teacher in managing and developing learning material and can prepare the learning design better. In addition to facilitating the teacher, students also gain experience as well as comprehensive knowledge because the learning process sequence is not partial. In this context all the interrelated themes are connected and integrated in a series of learning processes so that students get their understanding and learning experience holistically.

The series of integrated learning processes in elementary schools is built from a collection of learning contents that are interrelated with each other and the competencies. In this context, there is no sequence of material developed in accordance with the existing basic competencies but rather the relevance of the material that can be developed within the scope of the themes that have been prepared. One of the contents of elementary school subjects that students learn is natural science which is included in one of the several learning content learned. The content of learning material for natural science was developed by raising themes related to nature, both biotic and abiotic environments, as well as natural resources that also influence the life processes of living things themselves.

Natural science is a collection of knowledge obtained through a particular method (Wonoraharjo, 2010, p. 12). In different references it is said that natural science is basically a unity between processes, attitudes, and priduk or interrelated results (Asy'ari, 2006, pp. 2 - 21). Natural science basically includes four main elements, namely: (1) attitude: curiosity about objects, natural phenomena, living things, and 
causal relationships that give rise to new problems that can be solved through the right procedure; natural science is open; (2) process: problem solving procedure through the scientific method; scientific methods include the preparation of hypotheses, the design of experiments or experiments, evaluations, measurements, and conclusions; (3) products: in the form of facts, principles, theories, and laws; and (4) application: application of scientific methods and concepts of natural science in everyday life (Sukamti, Januari 2018). The four main elements of natural science should appear in a series of learning processes that are the content of natural science learning. The content of natural science learning needs to be developed in a process that is challenging and able to optimize the way students think both asproblem solvers are also able to identify problems related to the material being studied in the real life context they experience.

The series of learning processes of natural science is developed using various approaches, strategies, methods, techniques, tactics, models and learning media that are relevant and able to optimize student competencies. In this case, the various approaches and media used must be affiliated in the context of the material developed based on the nature and development of the students themselves. So that the process implemented is really able to bridge between the goals achieved with basic abilities as the initial ability of students to carry out the learning process carried out. The basic assumption in this series is that the learning process of natural science needs to be developed using the right strategies to optimize the process.

The learning process of natural science needs to be developed in a series of learning processes in the context of the class by using various relevant and optimal learning media. Relevance in a global context needs to be developed by learning by using technology-based learning media by taking into account the resources and carrying capacity that are in school. One that exists today is learning science using a PC Tab device in the form of e-sabak. The use of this device was developed to be able to provide direct experience to students in following the learning process in their class. The series of learning processes using e-sabak still does not leave the essence of learning itself. Learning by using e-sabak still requires the development of processes with various methods that are able to activate and optimize student competencies in the context of an active process approach. Students can make learning observations 
using this tool. In addition, students can carry out scientific processes in each step using this device.

Based on the release released from the results of research funded by UNICEF and carried out by the Ministry of Communication and Information, a collection of evidence found that there were around 30 million Indonesian children and adolescents as active internet users (Purwadi, 2014). The existence of these facts indicates that digital media is now the main choice of their communication channels (Setyawati, 2015, p. 126). With these facts, the developments that have taken place at this time have brought many changes in the series of social processes in the community. Worse, these conditions also affect how individuals socialize in a series of lives in the community. Therefore, the educational process in its implementation through learning also needs to integrate the use of technology in the series. Thus, what must be developed in a series of learning processes, especially the content of learning science in elementary schools, is the use of child-friendly and technologybased devices, one of which is in the form of e-sabak devices.

The use of e-Sabak for learning has actually been done by other countries, such as Brazil, Colombia, Peru, Jamaica, and the United States. Then, the use of e-Sabak was followed by Thailand, India, Singapore, South Korea, China, Japan, Kasakhatan, Turkey, South Africa, England, France and Mauritius, and also followed by Australia (Warsihna, et al., Desember 2015). From various countries that have tested the use of tablets for learning, it can be concluded, among others: (1) students enjoy learning with tablets, (2) students can study anytime and anywhere, (3) students can learn independently, (4) tablets can be used for communication between students and between students and teachers, (5) tablets can be used for collaboration in doing assignments, and (6) students recognize mobile technology (Warsihna, et al., Desember 2015, p. 294).

The use of e-sabak has been developed and carried out in various countries including the Southeast Asia region. For the Southeast Asia region, the country that has already used tablets for education is Thailand. The results of a study conducted by Viriyapong and Harfield stated that consideration of the use of tablets for learning is: (1) ease of carrying allows tablets to be more comfortable to use in classrooms, 
(2) the cost of purchasing and maintaining tablets is cheaper than computer costs,

(3) children prefer touch screen and interactive technology, (4) pre-school children can learn to use tablets faster, freer, and more comfortable because they are free to explore (Virinyapong \& Harfield, 2013).

As Parsons and Oja said in Huber, e-Sabak is defined as a set of free computers that use touch screen technology and can be used to write and draw. Deeper stated about the types of tablets, such as tablets as sabaks (stationery) and as devices that resemble laptops. Although the tablet is not equipped with a keyboard, external equipment that functions as a dock for tablets and provides additional convenience, can be added (Huber, 2015). This tablet is used to help a person's work process in accordance with its designation. If the device is used in schools, the designation and programs embedded in it are tailored to the relevant learning material in schools, especially elementary schools.

Learning in general and on the content of learning science in elementary schools using e-sabak devices can almost all be applied. The process of learning natural science using e-sabak can be developed an effective and optimal process. In practical operation in the classroom, students can carry out the observation process using this device by taking pictures, videos, even with the features on this device students can observe and document in the form of video the process of growing soybeans from seeds to growing in a certain period. In addition, students can also take advantage of the dimensional dimensions of space with the virtual ruler feature provided. In addition to the observation process, students are also more interested in using this tool to record and document and then discuss it in group work to be presented in front of the class. The classroom atmosphere becomes life and student involvement can be optimized effectively.

The learning process of natural science using e-sabak tools will basically facilitate the teacher in planning, developing, implementing, and evaluating the learning process. In addition, administrative reporting of the learning process can be recorded and administered properly on this device. E-sabak helps the teacher in managing the administration administration of learning with attendance features and recording of 
learning activities carried out. The correlation with natural science learning in elementary schools is certainly very strong because the conceptual framework of the collection of natural science learning material is maximized through a series of stepby-step learning using this e-sabak device.

\section{METHOD}

This research method uses a qualitative descriptive approach. In its implementation, the research process is carried out using data collection methods in the form of interviews, direct observation, and documentation. Documentation was carried out during the implementation of the science load learning process in $4^{\text {th }}$ grade of state elementary school of Pondok Petir 01, Depok City. A qualitative approach is a research procedure that produces descriptive data in the form of speech or writing and observable behavior from the subject itself. A qualitative approach is a research approach carried out to explore and understand phenomena that occur in individuals in the social sphere (Creswel, 2014, p. 12). This approach is carried out to identify and raise individual issues in a social context in order to develop strategic steps in improving and living standards of a social environment in the community itself. However, this approach is not only limited to social problems but also able to raise the issue of individuals who are members of certain social groups to be communicated through the process of disseminating the results of the research conducted.

Nana Syaodih Sukmadinata in Suwandayani said that a series of qualitative descriptive research processes was carried out aimed at describing and describing various phenomena that occur, are natural and the results of human treatment itself, which pay more attention to the characteristics, quality, and inter-activity linkages (Suwandayani, Februari 2018, p. 82). Thus, this series of research processes does not provide any form of treatment, manipulation or alteration of the variables under study. This study analyzes the existence of how the application of natural science learning using e-sabak tools to $4^{\text {th }}$ grade students of state elementary school of Pondok Petir 01, Bojongsari, Depok City, West Java. 
The research was carried out for a period of 3 months, namely in August to October 2018. The place of research was conducted in the fourth grade of state elementary school of Pondok Petir 01, Depok City, located on Reni Jaya Selatan street, Pondok Petir, Bojongsari, Depok City, West Java.

One of the most important things in research is research data, because through data various kinds of research objectives can be achieved, both in terms of answering questions, and testing hypotheses (Silalahi, 2006, p. 257). Therefore, the step of data collection can be said to be one of the most essential steps in research. Research data is the result of observations and measurements made empirically, which reveal facts about the characteristics of a particular symptom. In the research process, researchers do not rely solely on rational knowledge, because often what is seen or heard every day is different from reality in the field. Therefore it is important to find and find facts as empirical knowledge, through data collection.

The method of recording data in this study uses two basic methods namely direct observation and documentation. Both of these methods are carried out as a control step in order to get the data that is really as expected and avoid data bias. Obtaining research data is done through the process of observation, documentation, and interviews with teachers and students involved in the series of learning processes in the load of natural science lessons in the fourth grade of state elementary school of Pondok Petir 01, Depok City. In the process, the researcher documented using a digital camera to obtain image data from a series of learning processes carried out through the use of e-sabak in learning the contents of natural science lessons in the fourth grade of state elementary school of Pondok Petir 01, Depok City.

After obtaining research data in the field, the next process is analyzing the data according to the type of data obtained in this series of research processes. Qualitative data analysis is an effort carried out through a series of work with data, organizing data, sorting it into manageable units, synthesizing it, finding and finding patterns, discovering what is important and what is learned and deciding what can be told to others (RC Bogdan, 1982, p. 172). Analysis is a study to look for patterns. The pattern here refers more to cultural patterns rather than solely to the social situation of a cultural domain is a category of cultural meanings involving smaller categories. 
Data analysis carried out during data collection led researchers to pace between thinking about existing data and developing strategies to collect new data (Matthew B Miles, 2014). In the process, correction of information that is not clear and directs the ongoing analysis is related to the impact of generating field work. The steps taken in data collection are compilation of contact summary sheets, making codes, coding patterns and giving memos.

The process of data analysis carried out in this series of studies was carried out through 3 sets of data analysis processes, namely: (1) open coding; (2) axial coding; (3) selective coding. Open coding is done by identifying categories, properties, and dimensions. The axial coding step is carried out by the process of developing relationships between the categories obtained. In selective coding a selection of the most basic categories is carried out systematically linking it with other categories and validating the relationship.

\section{RESULT AND DISCUSSION}

Research on the use of e-sabak in learning science content in class IV of State Elementary School of Pondok Petir 01, Depok City was carried out for a period of 3 months. In the series of lessons learned, students are active and in the learning process through a series of learning using e-sabak as a learning medium that is directly used by students. In the process, students are given an understanding and understanding regarding the use of these devices. In addition to students, teachers are also equipped with how to use and use e-sabak tools in the learning process in the classroom. The series of learning processes is carried out through steps in general, but at the core stage of learning an independent assistance is given to the students by the teacher using the e-sabak device that has been prepared. Students hold one PC Tab device (in this case e-Sabak) to find and identify the material to be learned. In the process of learning natural science through the use of e-sabak, students spend more time outside the classroom to obtain data by photographing and documenting independently with e-sabak devices.

Before students are proficient in using this tool, students and teachers are given debriefing on how to use the e-sabak tool in learning. Students are given an understanding of how to use this device in learning. Teachers are also given training 
and mentoring until they are truly able to use it in a series of learning processes in the classroom using this device. Previously the teacher was given 2 times training and 1 time assistance in practice in the classroom in the learning process using an e-sabak device. Debriefing and mentoring were carried out directly by the e-sabak vendor, PT. Telkom Indonesia. The stages of debriefing and training conducted by service providers namely PT. Telkom Indonesia, among others:

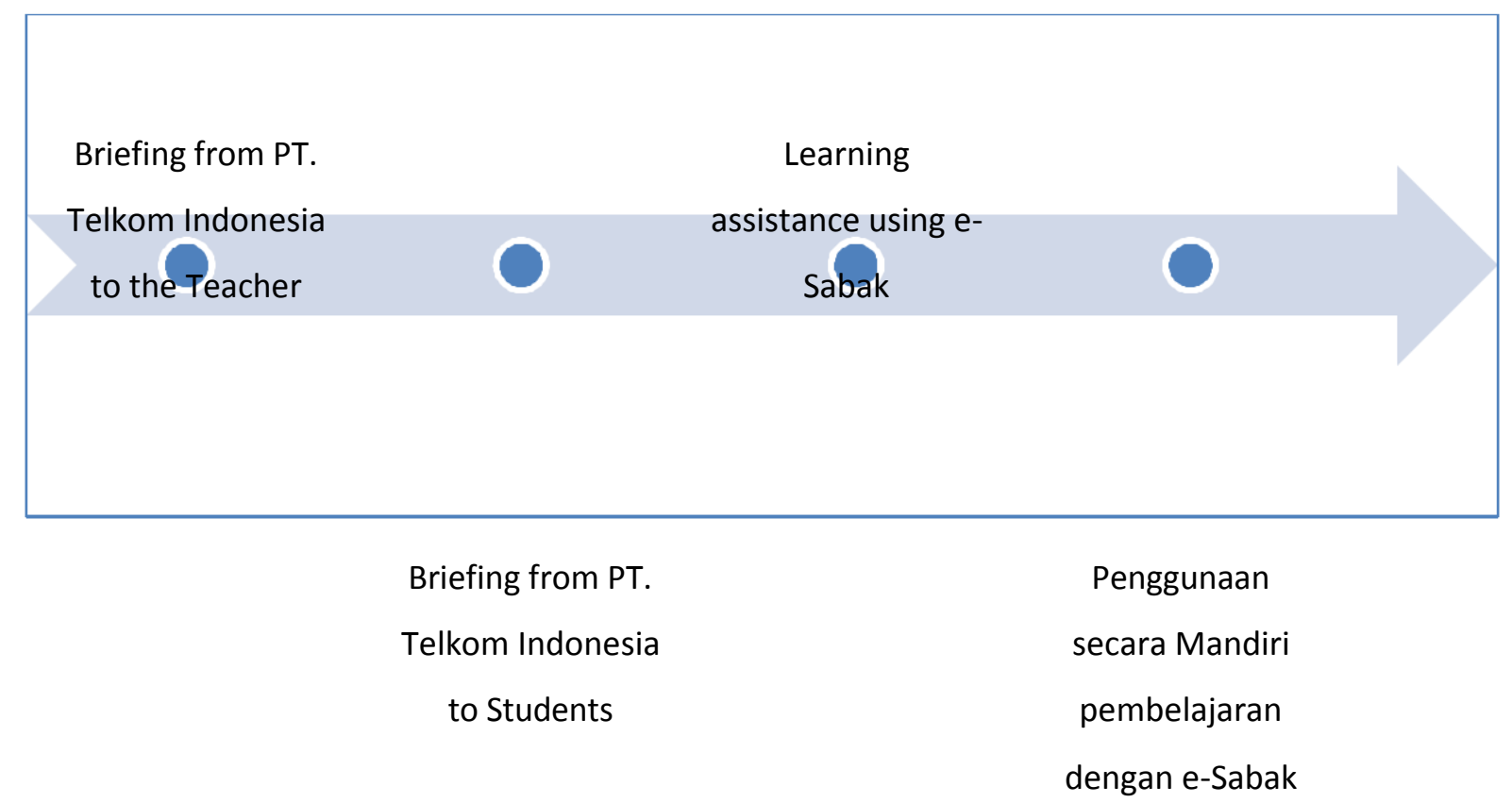

Figures 1. Flow of debriefing and assistance with e-sabak activities in learning.

In the process of debriefing until mentoring, PT. Telkom does not release directly when the teacher will use e-sabak in the learning process. The teacher needs to notify the previous week so that the schedule for use and assistance is arranged with PT. Telkom Indonesia. In its praxis for 5 times, there are 2 times the vendor cannot provide assistance because the schedule changes suddenly because the team already has a schedule in another school that cannot be contested. In the process of debriefing by the vendor team, there are still teachers who cannot attend or can be present but cannot be fully present and follow through. 


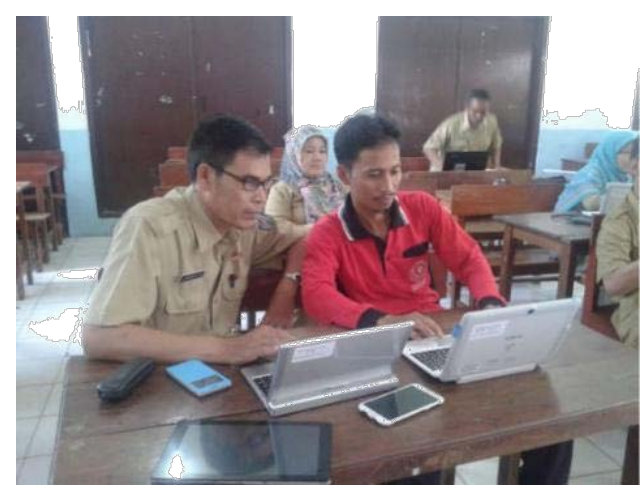

Figures 2. The first debriefing activity was to the teacher by a team from PT. Telkom Indonesia.

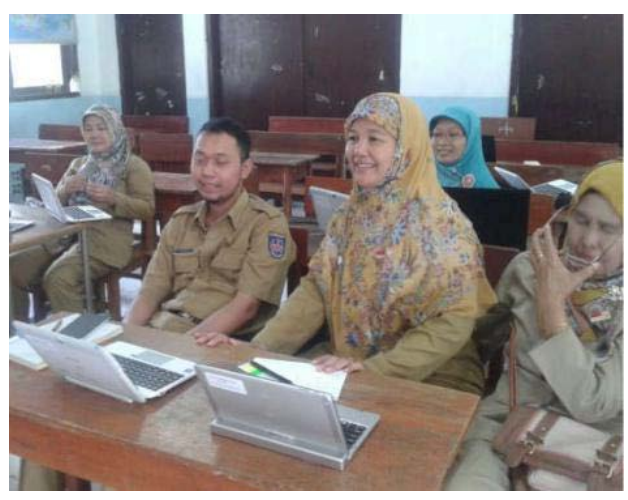

Figures 3. The second debriefing activity to the teacher by the team from PT. Telkom Indonesia.

The debriefing activity is carried out for a period of 1 month. Performed every two weeks scheduled every Monday or Wednesday. However, in practice there were still changes to the schedule which made some activities that had been scheduled to change. The debriefing process is intended so that the teacher is able to both practically and conceptually how to use the e-sabak tool in learning. In this case, the main goal here is how teachers are able to develop innovative learning sequences through the use of e-sabak devices in class. Thus, learning can be achieved meaningfully as expected. 


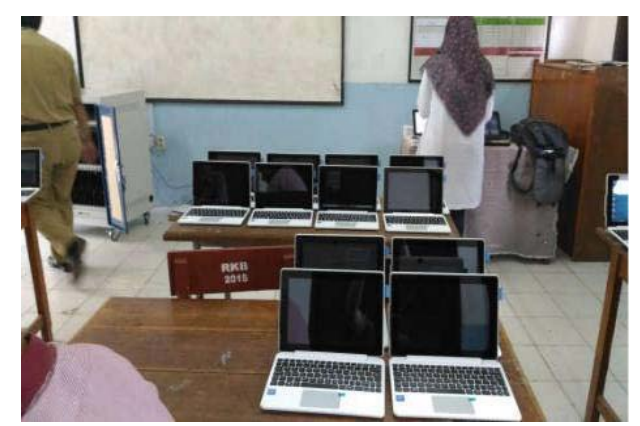

Figures 4. Briefing to students by the PT. Telkom Indonesia.

The debriefing activities for students in addition to being carried out by the teacher through the introduction then continued technically by a team from PT. Telkom Indonesia. In the process, the team experienced a few obstacles because it was unable to control the class. However, teachers in the class were able to control the atmosphere swiftly so that activities could be resumed smoothly and as expected.

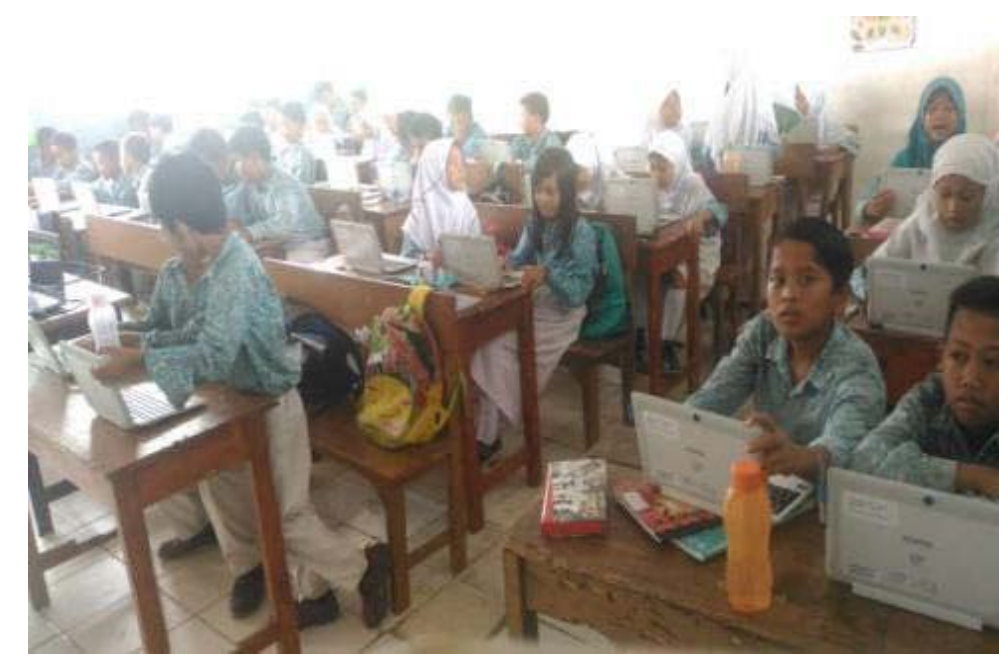

Figures 5. Debriefing activities for students by a team from PT. Telkom Indonesia.

In the next step, mentoring activities are carried out in the same format as the debriefing activities. However, more vendor teams are observers in the learning process. During the series of learning processes in the classroom, vendors just sit and pay attention to the back of the class taking notes and identifying using the monitoring sheet of the learning series using an e-sabak device. In the process, the teacher selects and determines the material to be learned. In the end, the teacher 
determined the content of learning science in class 4 which was developed through the use of e-sabak in the class.

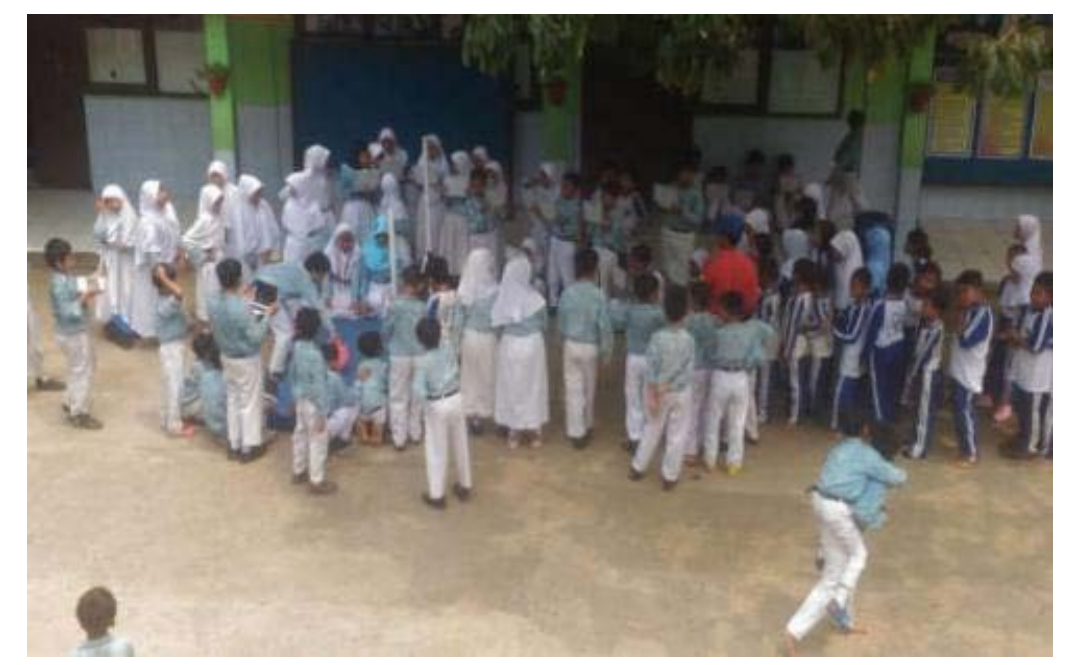

Figures 6. Observation activities by students in the natural science content learning series using e-sabak in fourth grade.

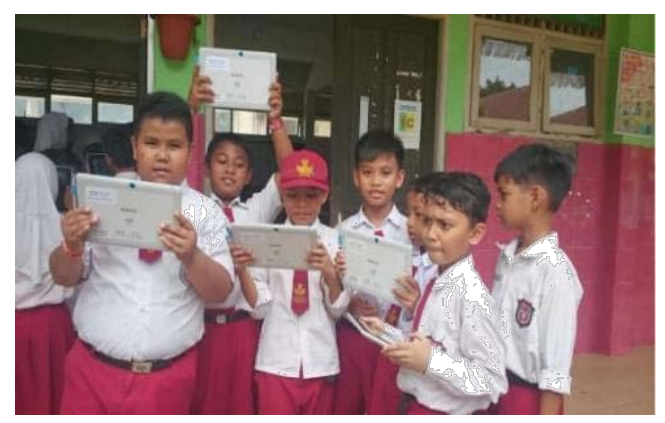

Figures 6. Observation activities by students in natural science content learning series using e-sabak in class 4 at other meetings.

The e-sabak device used consists of several instruments, including: (1) Student Tab PC; (2) Teacher Tab PC; (3) LCD Projector; (4) camera devices; (5) internet connection with LAN cable; (6) local server. The devices are connected systemically in a 24-hour connection which is also assisted by monitoring using 360 degree camera devices. However, the focus of this research is how to use e-sabak in a series of learning processes for the load of science lessons in grade 4 of elementary school. Here, the researcher reveals and documents and identifies how e-sabak devices as technology-based innovative media are able to optimize the learning 
content of natural science lessons in the classroom. Thus, what is the learning mouth here is how this device can be optimized in a series of learning activities.

The use of learning media in the series of learning processes in the classroom is obligatory. However, this must be adjusted to the conditions and development of students. In addition, the media used also need to consider the concept of material to be studied. Thus, what will be done in a series of learning can be optimized by using the right media. So, in the learning process carried out can provide valuable experience for students and can also be achieved optimally the expected learning competencies.

The learning process of the content of natural science was developed in a series of learning using integrated thematic approaches. However, the material that is developed still does not leave the identity of each of the contents of the lesson learned. There is no explicit identity in the lessons learned. However, the material concepts learned by students still show the identity of their respective subjects. In reality, the slices of the lesson content still appear to be interrelated to the lesson but are not shown to be identical to the content of the lesson that is present with the thematic framework being studied.

Based on the results of the research conducted, one outline can be identified in this series of research, namely the use of e-sabak tools optimizing learning content in natural science in a series of learning processes in grade 4 at State Elementary School of Pondok Petir 01, Bojongsari, Depok City, West Java . In this research process, descriptive data were obtained related to the use of e-sabak in the learning series of the load of natural science lessons in grade 4 at State Elementary School of Pondok Petir 01. Before the process of learning using e-sabak devices, a series of preparations related to the use of e-sabak were done first. technical in class and mainly is how teachers are able to optimize learning using these devices. Based on the results of interviews with teachers who were directly involved in the process of the activity (both debriefing, mentoring and use in learning) the vendor team was very enthusiastic and supported the teacher on how to use the e-sabak tool in the series of learning processes in the classroom. Students are very happy because they assume that they learn to use these devices like playing while learning. They feel happy because learning is not as serious as imagined. In addition, they are also 
not bored because learning is also done outside the classroom as is the step of observing and retrieving data by students in their school environment.

\section{CONCLUSION AND SUGGESTION}

Based on the results of the research conducted, it can be concluded a series of studies on the use of e-sabak in the learning process of the load of natural science lessons in grade $4^{\text {th }}$, state elementary school of Pondok Petir 01, Bojongsari, Depok City, West Java. The series of research processes were carried out over a period of 3 months, namely from August to October 2018. In the process, this research was conducted to obtain descriptive data about the use of e-sabak in the learning process of natural science learning in grade 4, state elementary school of Pondok Petir 01, Bojongsari, Depok City, West Java.

Learning activities using e-sabak devices are carried out independently by the teacher with students in the class. In the learning done, students independently use the e-sabak device one tool one student so that they feel directly using this tool in the learning done. The stages of the use of learning media are not directly used in the classroom, but are preceded by debriefing and training carried out directly by the vendor team (in this case, PT Telkom Indonesia). The debriefing stages carried out are for 4 steps, including: (1) debriefing to the teacher by the PT. Telkom Indonesia; (2) debriefing to students by the PT. Telkom Indonesia; (3) assistance in the use of e-sabak in learning by the PT. Telkom Indonesia; (4) the independent use of e-sabak tools in classroom learning by teachers under the monitoring of the PT. Telkom Indonesia.

The series of learning processes for the load of natural science lessons in fourth grade at state elementary school of Pondok Petir 01, Bojongsari, Depok City, West Java was developed over a period of 2 months. In the process learning is carried out by referring to the study of conceptual material students will learn in class. After obtaining relevant material that can be developed, the learning steps are developed by including the use of e-sabak tools in the learning done. In the process, students carry out the learning process in several specified locations. Learning begins with an understanding of the material to be developed in the classroom. Furthermore, students observe and obtain data by taking photos and taking video documents in 
the field based on the object they are learning. Furthermore, students take advantage of the existing environment (other than in the classroom) to discuss in groups from what they get in the field. The last activity carried out was the students in groups presented their observations in the field based on group discussions that had been conducted. At that time students were learning the concept of saving energy and its implementation in the process of everyday life.

\section{REFERENCES}

\section{Book}

Asy'ari, M. (2006). Penerapan Pendekatan Sains-Teknologi-Masyarakat dalam Pembelajaran Sains di Sekolah Dasar. Yogyakarta: Universitas Sanata Dharma.

B.R. Hergenhahn, M. H. (2008). Theories of Learning, terjemahan oleh Triwibowo B.S. (1 ed.). Jakarta: Kencana Prenada Media Group.

Creswel, J. C. (2014). Research Design: Qualitative, Quantitative, and Mixed Method Approaches. California: Sage Publications.

Hamalik, O. (2011). Kurikulum dan Pembelajaran (1 ed.). Jakarta: Bumi Aksara. Matthew B Miles, M. H. (2014). Qualitative Data Analyze: A Method Source Book. London: Sage Publishing.

RC Bogdan, S. B. (1982). Qualitative Research for Education: An Intruduction to Theory and Methods. Boston: Allyn and Bacon.

Silalahi, U. (2006). Metode Penelitian Sosial. Bandung: Unpar Press.

Trianto. (2007). Model Pembelajaran Terpadu dalam Teori dan Praktik. Jakarta: Prestasi Pustaka.

Wonoraharjo, S. ( 2010). Dasar-dasar Sains. Jakarta: Indeks.

\section{Journals/ Proceedings/ Dissertations/ Theses}

Setyawati, G. (2015). Dampak Teknologi dan Proses Pembelajaran Berbasis Teknologi dalam Membentuk Perilaku Anak SD. Seminar Nasional Fakultas Psikologi Universitas Muria Kudus (pp. 126 - 134). Kudus: Fakultas Psikologi Universitas Muria Kudus.

Suwandayani, B. I. (Februari 2018). Analisis Perencanaan Pembelajaran Tematik pada Kurikulum 2013 di Sekolah Dasar Negeri Kauman 1 Malang. Elementary School Education Journal, Vol 2, No. 1(UM Surabaya), 78 - 88. 
Virinyapong, R., \& Harfield, A. (2013). Facing the challenges of the One-TabletPer-Child policy in Thai primary school education. International Journal of Advanced Computer Science and Applications, Vol 4, No. 9(2013).

Warsihna, J., Mutmainah, S., \& Utari, I. (Desember 2015). E-Sabak untuk Pembelajaran di Indonesia. Jurnal Teknodik, Vol 19, No. 3(Pustekkom Kementerian Pendidikan dan Kebudayaan ), 293 - 304

\section{Others}

Huber, S. (2015, Februari 12). iPads in the Classroom - A Development of a Taxonomy for the Use of Tablets in Schools. Retrieved November 2, 2018, from http://l3t.eu/itug/images/band2.pdf

Purwadi, D. (2014, Februari 18). Riset: 30 Juta Anak Indonesia Pengguna Internet.

Retrieved from http://www.republika.com:

http://www.republika.co.id/berita/nasional/umum/14/02/18/n174jc-riset-30-jutaanakindonesia-pengguna-internet

Sukamti, E. U. (Januari 2018). Pelaksanaan Pembelajaran IPA SD Kurikulum 2013 pada Kelas Atas di Sekolah Dasar Kota Blitar. Retrieved November 9, 2018, from http://lib.um.ac.id/index.php/2018/01/07/pelaksanaan-pembelajaran-ipasd-kurikulum-2013-pada-kelas-atas-di-sekolah-dasar-kota-blitar/

\section{ABOUT THE AUTHORS}

Muhammad Fajri: as a teacher in State Primary School of Pondok Petir 01, Bojongsari, Depok City, West Java, Indonesia 